\title{
Change of guard for Australian science
}

Astronomer Penny Sackett is to be Australia's next chief scientist, taking over from Jim Peacock in November, the government announced last week.

It is not the only change at the top of Australian science: geologist Megan Clark will become head of the national research agency, the CSIRO, in January. Meanwhile, the Australian Stem Cell Centre is without a permanent leader after its chief executive was sacked in July, and the entire board resigned amid controversy in September. An interim chair of the board, Graham Macdonald, has been appointed.

Sackett's appointment has been greeted with broad approval by researchers. The US-born scientist, originally from Lincoln, Nebraska, has lived in Australia since 2002, when she was recruited to head the Mount Stromlo and Siding Spring Observatories, and to run the astronomy and astrophysics department at the Australian National University in Canberra. Sackett has also been involved in the governance of the
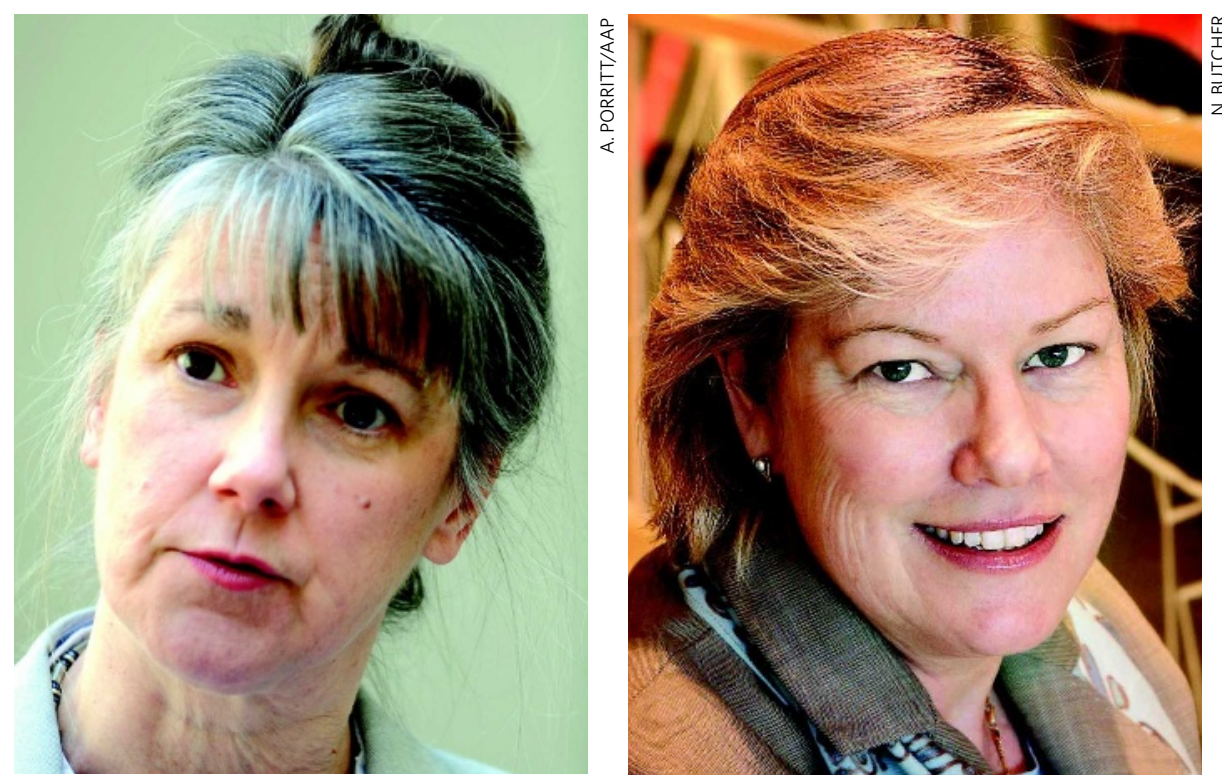

New guard: Penny Sackett (left) and Megan Clark will take two of Australia's top science jobs. Gemini Observatory, the Hubble Space Telescope and the Giant Magellan Telescope.

The job of chief scientist will be made a full-time post, upgraded from part-time, once Peacock, a CSIRO plant scientist, leaves next month. The purpose of the role is to provide the government with independent advice on scientific matters relating to policy. Sackett will need to shake offlong-standing concern about political interference in the post. Her predecessors have been criticized for siding with the government on some controversial decisions, such as Peacock's support of an environmentally controversial pulp mill and his predecessor Robin Batterham's dismissal of the Kyoto Protocol on climate change (see Nature 435, 398; 2005).

Sackett says she discussed these issues openly with the government before accepting

science within the ministry of innovation," says Kurt Lambeck, president of the Australian Academy of Science. But Sackett is confident that there are other lines of communication, including the Prime Minister's Science, Engineering and Innovation Council.

When Kevin Rudd's Labor government came to power at the end of 2007, it instigated a swag of reviews, and their findings are beginning to emerge. One such review, released last month, calls for university research to be fully publicly funded - currently, universities must find some of their costs from other sources. The review also calls on the government
"The ground rules we agreed on are complete independence of advice and a 'no-surprises' policy." to step up research spending to match other nations in the Organisation for Economic Co-operation and Development. "The chief scientist will play a major role in shaping the government's response to the post. "The ground rules we agreed on are complete independence of advice and a 'nosurprises' policy. It would not be productive if the first time the government heard the advice was by reading it in the newspaper," she says. "The advice would be independent and not adversarial," Sackett adds.

Some are concerned about the fact that the chief scientist reports directly to the minister for innovation, industry, science and research, rather than the prime minister. "It is very important that the chief scientist is representative of all Australian science, and not just the experience, and I think she will do what she sees as best for the organization," he says.

Things are not looking as rosy at the Australian Stem Cell Centre in Melbourne, a biotech founded with public money in 2003 by Alan Trounson, who now heads the California Institute for Regenerative Medicine in San Francisco. On 5 September, the board resigned after accusing stakeholder universities of not supporting its independence. A week earlier, the board had sacked the centre's chief executive, Stephen Livesey, because of differences over the commercial direction of the centre. During subsequent consultations on the centre's future direction, the board and some university partners clashed over control of the board.

"We saw resignation as the only option available," says Vicki Sara, ex-chair of the centre's board and chancellor of the University of Technology Sydney. Sara says that, by moving aside, the outgoing board hopes that a fresh approach will attract long-term government funding.

Original expectations that the centre would be financially self-sufficient after current government funding expires in June 2011 were "unrealistic", says interim chair Macdonald. The immediate objective is to redesign the centre's business plan. A minimal model, says Macdonald, could provide the stem-cell community with management, commercialization advice and technology services on intellectual property. "The objective is to resolve those questions within the next month and a half," he says.

Carina Dennis 